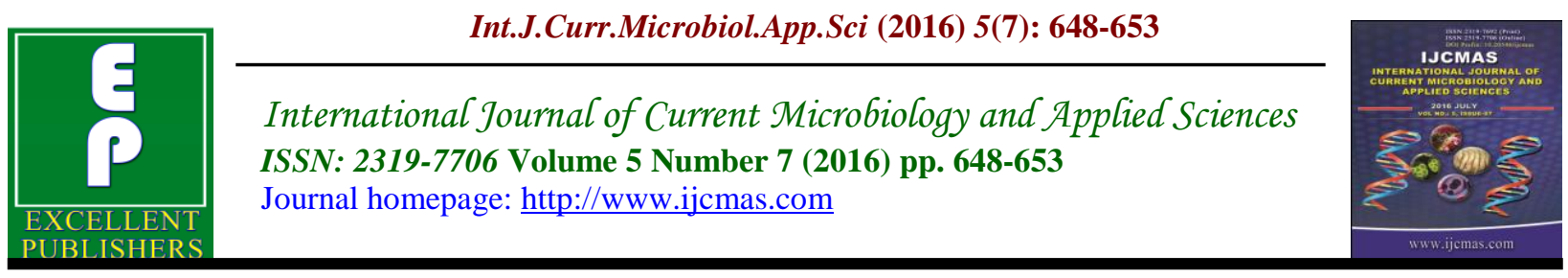

Original Research Article

http://dx.doi.org/10.20546/ijcmas.2016.507.073

\title{
Effect of Dietary Treatments using Melon Shell on the Hematology of Catfish (Clarias gariepinus, Burchell 1822) Fingerlings
}

\author{
E.E. Omovwohwovie ${ }^{1}$ and J.K. Ekelemu ${ }^{2^{*}}$ \\ ${ }^{1}$ Department of Fisheries Technology, Federal Polytechnic Ekowe, Bayelsa State \\ ${ }^{2}$ Department of Fisheries, Delta State University, Asaba Campus, Asaba \\ *Corresponding author
}

\begin{abstract}
A B S T R A C T
Keywords

Diets, melon shell, treatments, hematology, fingerlings.

\section{Article Info}

Accepted:

22 June 2016

Available Online:

10 July 2016

Effect of using diets containing melon shell as replacement on the hematological profile of Clarias gariepinus fingerling was evaluated for twelve weeks. Five diets havimg a GP of $40 \%$ were prepared and their proximate analysis carried out. The melon shell was used to replace maize at 0\% (Diet 1), 25\% (Diet 2, 50\% (Diet 3), 75\% (Diet 4), and 100\% (Diet 5). Each treatment had three replicates using 30 Clarias gariepinus fingerlings per replicate in concrete tanks measuring $1 \mathrm{~m} \mathrm{x} 1 \mathrm{~m} \mathrm{x}$ $1 \mathrm{~m}$. The fingerlings were fed at $3 \%$ body weight twice per day for 12 weeks. Data obtained were analyzed using analysis of variance (ANOVA) and the new Duncan's multiple range test (NDMRT) and Pearson's correlation matrix. Results obtained showed blood parameters (PVC, HB, RBC, WBC, and Plasma protein) were significantly different $(\mathrm{P}<0.05)$ among experimental fishes. Higher level of $\mathrm{PCV}, \mathrm{WBC}$ were observed in fish fed Diet 5, while $\mathrm{Hb}, \mathrm{RBC}$ and plasma protein were higher in fishes fed Diet 4 . The findings showed significant difference $(\mathrm{P}<0.05)$ in the hematological values of experimental fish with increase in the replacement level of melon shell in the diets. This did not however negatively affect the condition factor $(\mathrm{K})$ and heath status of the fish.
\end{abstract}

\section{Introduction}

Life is possible only through the metabolic processes of cells, mainly by requiring constant supply of nutrients, and oxygen and by constant removal of waste products. In vertebrates, metabolic processes is done in the blood vascular system, which regulates the life activities that are seen in the homeotherms and poikilotherms because it is the communicating tissue and medium for all the cells of a body. Fishes belonging to different taxonomic groups are adopted variously depending on different prevailing ecological conditions. Haematological characteristic is an important tool that can be used as an effective and sensitive index to monitor physiological and pathological changes in fishes (Satheeshkuar and Ananthan 2012). Changes in haematological parameters depend upon the aquatic biotope, fish species, age, and sexual maturity and health status (Patriche et al., 2011; Radu et al., 2009).Various blood parameters in fish have been established by different investigators in fish physiology and 
pathology (Satheeshkumar et al., 2012, Fazio et al., 2013).

Haematological studies help in understanding the relationship of blood characteristics to the habitat and adaptability of the species to the environment. The fish haematological parameters such as RBC, $\mathrm{WBC}, \mathrm{Hb}$ and PCV values etc., are thus shown to be influenced by many factors include feed intake (Pandey, 1977). So it is more beneficial to aquaculturists to study the varying aspects of haematological changes in different conditions. This study deals with the comparison of important blood parameters of Clairas gariepinus fed graded level of melon shell as replacement for maize

\section{Materials and Methods}

\section{Formulation of Experimental Feed}

Five diets having a crude protein of $40 \%$ each were formulated and used for the study The diets were formulated using the Pearson square method of feed formulation The experimental diets contained varying inclusion levels of melon shell as replacement for maize at $0 \%$ Diet $125 \%$ Diet 2, 50\% Diet 3, 75\% Diet 4 and 100\% Diet 5 (Table 1). A proximate analsis of the prepared diets was subsequently conducted. Five hundred (500) Clarias gariepinus fingerlings were purchased from a commercial fish farm in Asaba and transported in a jerry-can to the research site. Here they were kept in a $1 \mathrm{~m} \times 1 \mathrm{~m} x$ $1 \mathrm{~m}$ concrete tank and fed with fish meal to satiation for three days to acclimate. The fingerlings were thereafter randomly distributed in 30's into 15 concrete tanks of dimension $1 \mathrm{~m} \times 1 \mathrm{~m} \times 1 \mathrm{~m}$. The fifteen tanks were grouped in 3's to form 5 treatments (1$5)$ in triplicates $(\mathrm{A}-\mathrm{C})$ Fish in the treatment tanks were starved for 48hours to prepare their appetite for the formulated diets.
Fingerlings in each treatment tank were fed diets with the corresponding number to the tanks at a body weight of $3 \%$ for twelve weeks. Thereafter five fish from each treatment were randomly sampled to assess the effects of dietary treatments on the haematological profile of the fish samples at the end of the feeding trials

\section{Blood sample collection}

A small sample of blood was drawn from the caudal vein by introducing disposable sterile syringe $(2.5 \mathrm{~mL})$ and transferred in a mini plastic $0.5 \mathrm{ml}$ tube containing EDTA $(1.26 \mathrm{mg} / 0.6 \mathrm{ml})$ as an anticoagulant, for blood cell studies, and the other without EDTA allowing the clot and serum to separate for protein estimation. The collected blood samples were immediately subjected to hematological analysis.

\section{Analysis of Hematological parameters}

The blood samples were diluted with appropriate diluting fluids for $\mathrm{RBC}$ and WBC counts and were determined using improved Neubauer hemocytometer and calculated (Blaxhall and Daisley, 1973). Replicated counts were made for each blood samples to minimize the error. The hemoglobin was determined by cyanmethemoglobin method (Lee et al., 1998). Hematocrit (Hct) was determined by the microhematocrit method (Snieszko, 1960). Mean Corpuscular Volume (MCV) was calculated according to Feldman et al., (2000). Mean Corpuscular Hemoglobin $(\mathrm{MCH})$ and Mean Corpuscular Hemoglobin concentration (MCHC) were calculated according to Stoskopf (1993).

\section{Statistical Analysis}

The data collected were analyzed Statistically using analysis of variance (ANOVA) and the differences among means 
were tested for significance $(\mathrm{P}<0.05)$ using Duncan multiple range test (SPSS 16.0). Pearson (r) correlation was used to evaluate the inter-relationship between the different hematological parameters and condition factor.

\section{Result and Discussion}

Presented in Tables 1 and 2 are the experimental diets and proximate compositions of the diets.

The results of the blood parameters of Clarias gariepinus fed diets with various levels of melon shell in terms of pack cell volume (PCV), Haemoglobin $(\mathrm{Hb})$, red blood count (RBC), white blood count (WBC), and total protain (TP) are presented in Table 3.

PCV ranged between $30.0 \%$ in fish fed diet one and $40.0 \%$ in fish fed diet five. Also $\mathrm{RBC}$ ranged between $\left(3.11 \mathrm{million} / \mathrm{mm}^{3}\right)$ in fish fed diet four and $1.8 \mathrm{million} / \mathrm{mm}^{3}$ in fish fed diet five. Total protein ranged between $5.0 \mathrm{~g} / \mathrm{dl}$ in fish fed diet four and $3.5 \mathrm{~g} / \mathrm{dl}$ in fish fed diet five. White blood count (WBC) shows a decrease value observed with increase in replacement level of melon sheli in the diets from $5000 \mathrm{cell} / \mathrm{mm}^{3}$ in fish fed diet one and 7000 cell $/ \mathrm{mm}^{3}$ in fish fed diet five. Haemoglobin $(\mathrm{Hb})$ ranged between 13.167 in fish fed diet four and 10.03 in fish fed diet one and five. PCV, Hb, WBC, and TP values show significant differences $(\mathrm{P}<0.05)$ among groups. $\mathrm{PCV}$ increases significantly $(\mathrm{P}<0.05)$, with increase in replacement level of melon shell among treatments. Diet one is not significantly difference $(\mathrm{P}>0.05)$ different from diet five but differ significantly $(\mathrm{P}<0.05)$ from fish fed diet two, three and four.

The blood parameters of this study, (PVC, $\mathrm{HB}, \mathrm{RBC}$, WBC, and Plasma protein) shows significant difference $(\mathrm{P}<0.05)$ among experimental fish. Significant changes in the PCV and WBC of experimental fish increase as inclusion level of melon shell increase. This observation is not in line with the work of Omitoyin (2006) who reported gradual decrease in blood parameters as inclusion level of poultry liter increase in the diets of Clarias gariepinus. RBC level was highest in fish fed diet containing $75 \%$ inclusion of melon shell which had a value of $(3.11 \times$ $\left.10^{6} / \mathrm{mm}^{3}\right)$. This was followed by fish fed diet three $\left(2.42 \times 10^{6} / \mathrm{mm}^{3}\right)$, reduce to diet two $\left(2.34 \times 10^{6} / \mathrm{mm}^{3}\right)$, control diet $(2.23 \times$ $\left.10^{6} / \mathrm{mm}^{3}\right)$ down to diet five $(1.80 \mathrm{x}$ $\left.10^{6} / \mathrm{mm}^{3}\right)$. However, these values were similar to the RBC values observed for fresh water fish, like Clarias batrachus 2.1× $10^{6} / \mathrm{mm}^{3}$ and Labeo rohita $2.0 \times 10^{6} / \mathrm{mm}^{3}$ (Sudha Summarwar and Santosh Verma, 2012), Sparus aurata $3.49 \times 10^{6} / \mathrm{mm}^{3}$ and Dicenterchus labrax $3.06 \times 10^{6} / \mathrm{mm}^{3}$ (Fazio, Arfuso, Piclione and Faggio, 2013). WBCs are the suspicious cells of the body. According to Dauglas and Jane (2010), their levels have implications for immune responses and the ability of the animal to fight infections. Species with high levels of WBC will be able to fight infection more effectively. Findings from this study showed that WBC count increased with increase in inclusion level of melon shell, with wide variation of $5.0 \times 10^{3} / \mathrm{mm}^{3}$ in fish fed control diet, to $7.0 \times 10^{3} / \mathrm{mm}^{3}$ in fish fed Diet five. This observation shows that fish fed diet five ( $100 \%$ melon shell) will be able to fight infection more effectively than fish fed control diet ( $0 \%$ melon shell). The inverse relationship between $\mathrm{WBC}$ and $\mathrm{RBC}$ in this present study was also reported by Satheeshkumar et al, (2010) on seven different teleost fishes. PCV value ranged from 40.0 in fish fed diet five $(100 \%$ melon shell) to 30.0 in fish fed diet one. PCV concentration increased with increase in melon shell inclusion. This may be due to 
high value of cellular component of the blood (Fuzio et al., 2013). Plasma protein ranged from $3.5 \mathrm{mg} / 100 \mathrm{ml}$ in fish fed diet five to $5.0 \mathrm{mg} / 100 \mathrm{ml}$ in fish fed diet four.
This range is in line with the work of Sudha et al, (2012) who reported $5.1 \mathrm{mg} / 100 \mathrm{ml}$ for Catla catla, $3.9 \mathrm{mg} / 100 \mathrm{ml}$ for L. rohita and C. carpio $3.1 \mathrm{mg} / 100 \mathrm{ml}$.

Table.1 Ingredients and nutrient Composition of Experimental Diets

\begin{tabular}{|c|c|c|c|c|c|}
\hline Ingredient & $0 \%$ & $25 \%$ & $50 \%$ & $75 \%$ & $100 \%$ \\
\hline $\begin{array}{l}\text { Fish } \\
\text { meal }(\mathrm{g})\end{array}$ & 28.6 & 28.6 & 28.6 & 28.6 & 28.6 \\
\hline $\begin{array}{l}\text { Groundnut } \\
\text { cake }(\mathrm{g})\end{array}$ & 18.9 & 18.9 & 18.9 & 18.9 & 18.9 \\
\hline $\begin{array}{l}\text { Soya bean } \\
\text { meal }(\mathrm{g})\end{array}$ & 17.7 & 17.7 & 17.7 & 17.7 & 17.7 \\
\hline Maize (g) & 24.9 & 18.7 & 12.8 & 6.5 & - \\
\hline Melon (g) & - & 6.5 & 12.8 & 18.7 & 24.9 \\
\hline $\begin{array}{l}\text { Bone } \\
\text { meal }(\mathrm{g})\end{array}$ & 3.0 & 3.0 & 3.0 & 3.0 & 3.0 \\
\hline Lysine(g) & 2.0 & 2.0 & 2.0 & 2.0 & 2.0 \\
\hline $\operatorname{Premix}(\mathrm{g})$ & 2.0 & 2.0 & 2.0 & 2.0 & 2.0 \\
\hline Oil(g) & 1.0 & 1.0 & 1.0 & 1.0 & 1.0 \\
\hline $\begin{array}{l}\text { Methionine } \\
\text { (g) }\end{array}$ & 2.0 & 2.0 & 2.0 & 2.0 & 2.0 \\
\hline
\end{tabular}

Table.2 Proximate Composition of Experimental Diets

\begin{tabular}{lllllllll}
\hline & Sample Diet & \% Moisture & \%Ash content & $\begin{array}{l}\text { \%Crude } \\
\text { fiber }\end{array}$ & $\begin{array}{l}\text { \%Ether } \\
\text { Extract }\end{array}$ & $\begin{array}{l}\text { \% Crude } \\
\text { protein }\end{array}$ & $\begin{array}{l}\text { \%Nitrogen } \\
\text { extract (NFE) }\end{array}$ \\
\hline 1 & Control & 10.3 & 3.1 & 8.5 & 7.9 & 39.9 & 30.6 \\
2 & $25 \%$ & 8.9 & 3.1 & 10.2 & 13.5 & 39.7 & 24.4 \\
3 & $50 \%$ & 8.5 & 3.8 & 11.1 & 15.4 & 39.8 & 21.8 \\
4 & $75 \%$ & 8.4 & 4.1 & 12.0 & 16.4 & 39.9 & 19.4 \\
5 & $100 \%$ & 7.6 & 4.3 & 12.9 & 17.4 & 40.2 & 17.9 \\
6 & Melon Shell & 9.0 & 7.40 & 5.0 & 16.6 & 10.5 & 5.4 \\
\hline
\end{tabular}

Table.3 Summary of Analysis of Variance for Haematological profile of Clarias gariepinus fingerlings Fed Graded level of Melon Shell Diets

\begin{tabular}{llllll}
\hline Parameters & $\begin{array}{l}\text { 0\% inclusion of } \\
\text { melon shell }\end{array}$ & $\begin{array}{l}25 \% \text { inclusion of } \\
\text { melon shell }\end{array}$ & $\begin{array}{l}50 \% \text { inclusion of } \\
\text { melon shell }\end{array}$ & $\begin{array}{l}75 \% \text { inclusion } \\
\text { of melon shell }\end{array}$ & $\begin{array}{l}100 \% \\
\text { of melon shell }\end{array}$ \\
\hline & & & & & \\
& & & & \\
$\mathrm{PCV} \%$ & $30.000 \pm 1.0^{\mathrm{e}}$ & $32.000 \pm 1.000^{\mathrm{d}}$ & $34.000 \pm 1.000^{\mathrm{c}}$ & $37.00 \pm 1.0^{\mathrm{b}}$ & $40.00 \pm 1.000^{\mathrm{a}}$ \\
$\mathrm{Hb}(\mathrm{glc})$ & $10.033 \pm 0.153^{\mathrm{d}}$ & $10.433 \pm 0.252^{\mathrm{c}}$ & $12.20 \pm 0.1^{\mathrm{b}}$ & $13.167 \pm 0.153^{\mathrm{a}}$ & $10.033 \pm 0.152^{\mathrm{d}}$ \\
$\mathrm{WBC}\left(\mathrm{cel} / \mathrm{mm}^{3}\right)$ & $5.0 \pm 100.0^{\mathrm{e}}$ & $5.1 \pm 100.00^{\mathrm{d}}$ & $5.5 \pm 100.0^{\mathrm{c}}$ & $6.1 \pm 100.0^{\mathrm{b}}$ & $7.0 \pm 100.00^{\mathrm{a}}$ \\
$\mathrm{RBC}\left(\mathrm{mil} / \mathrm{mm}^{3}\right)$ & $2.23 \pm 0.04^{\mathrm{d}}$ & $2.34 \pm 0.02^{\mathrm{c}}$ & $2.42 \pm 0.02^{\mathrm{b}}$ & $3.11 \pm 0.02^{\mathrm{a}}$ & $1.80 \pm 0.04^{\mathrm{e}}$ \\
$\mathrm{Plasma} \quad$ protein & $4.0 \pm 0.10^{\mathrm{d}}$ & $4.50 \pm 0.10^{\mathrm{c}}$ & $4.70 \pm 0.10^{\mathrm{b}}$ & $5.00 \pm 0.10^{\mathrm{a}}$ & $3.50 \pm 0.10^{\mathrm{e}}$ \\
(gldc) & & & & &
\end{tabular}

Means with the same alphabets as superscripts on the same row are not significantly different $(\mathrm{P}>0.05)$ 
Table.4 Correlation Matrix of Haematological Parameters and condition factor

\begin{tabular}{|c|c|c|c|c|c|c|c|c|c|c|}
\hline & & $\begin{array}{l}\text { PCV } \\
(\%)\end{array}$ & $\begin{array}{l}\mathrm{Hb} \\
(\mathrm{g} / \mathrm{l})\end{array}$ & $\begin{array}{l}\text { WBC } \\
\text { (cells/mm3) }\end{array}$ & $\begin{array}{l}\text { RBC } \\
\text { (millions/mm3) }\end{array}$ & $\begin{array}{l}\text { Plasma } \\
\text { protein (g/dl) }\end{array}$ & MCV & MCH & MCHC & $\begin{array}{l}\text { Condition } \\
\text { factor }\end{array}$ \\
\hline \multirow[t]{3}{*}{ PCV (\%) } & Pearson Correlation & 1 & & & & & & & & \\
\hline & Sig. (2-tailed) & & & & & & & & & \\
\hline & $\mathrm{N}$ & & & & & & & & & \\
\hline \multirow[t]{3}{*}{$\mathrm{Hb}(\mathrm{g} / \mathrm{l})$} & Pearson Correlation & .231 & 1 & & & & & & & \\
\hline & Sig. (2-tailed) & .408 & & & & & & & & \\
\hline & $\mathrm{N}$ & 15 & 15 & & & & & & & \\
\hline \multirow{3}{*}{$\begin{array}{l}\text { WBC } \\
\text { (cells/mm3) }\end{array}$} & Pearson Correlation & $.957^{* *}$ & .077 & 1 & & & & & & \\
\hline & Sig. (2-tailed) & .000 & .785 & & & & & & & \\
\hline & $\mathrm{N}$ & 15 & 15 & 15 & & & & & & \\
\hline \multirow{3}{*}{$\begin{array}{l}\text { RBC } \\
\text { (millions/mm3) }\end{array}$} & Pearson Correlation & -.077 & $.865^{* *}$ & -.217 & 1 & & & & & \\
\hline & Sig. (2-tailed) & .786 & .000 & .437 & & & & & & \\
\hline & $\mathrm{N}$ & 15 & 15 & 15 & 15 & & & & & \\
\hline \multirow{3}{*}{$\begin{array}{l}\text { Plasma } \\
(\mathrm{g} / \mathrm{dl})\end{array}$} & Pearson Correlation & -.172 & $.849^{* *}$ & -.374 & $.905^{* *}$ & 1 & & & & \\
\hline & Sig. (2-tailed) & .540 & .000 & .169 & .000 & & & & & \\
\hline & $\mathrm{N}$ & 15 & 15 & 15 & 15 & 15 & & & & \\
\hline \multirow[t]{3}{*}{$\mathrm{MCV}$} & Pearson Correlation & .348 & $-.645^{* *}$ & .415 & $-.914^{* * *}$ & $-.782^{* *}$ & 1 & & & \\
\hline & Sig. (2-tailed) & .204 & .009 & .124 & .000 & .001 & & & & \\
\hline & $\mathrm{N}$ & 15 & 15 & 15 & 15 & 15 & 15 & & & \\
\hline \multirow[t]{3}{*}{$\mathrm{MCH}$} & Pearson Correlation & .448 & $-.526^{*}$ & .444 & $-.776^{* *}$ & $-.611^{*}$ & $.890^{* *}$ & 1 & & \\
\hline & Sig. (2-tailed) & .094 & .044 & .097 & .001 & .015 & .000 & & & \\
\hline & $\mathrm{N}$ & 15 & 15 & 15 & 15 & 15 & 15 & 15 & & \\
\hline \multirow[t]{3}{*}{$\mathrm{MCHC}$} & Pearson Correlation & .070 & -.388 & .159 & -.056 & -.361 & -.128 & -.054 & 1 & \\
\hline & Sig. (2-tailed) & .804 & .153 & .571 & .844 & .186 & .650 & .847 & & \\
\hline & $\mathrm{N}$ & 15 & 15 & 15 & 15 & 15 & 15 & 15 & 15 & \\
\hline \multirow[t]{3}{*}{ Condition factor } & Pearson Correlation & -.500 & $-.608^{*}$ & -.425 & $-.524^{*}$ & -.402 & .283 & .157 & .002 & 1 \\
\hline & Sig. (2-tailed) & .058 & .016 & .114 & .045 & .138 & .307 & .577 & .994 & \\
\hline & $\mathrm{N}$ & 15 & 15 & 15 & 15 & 15 & 15 & 15 & 15 & 15 \\
\hline
\end{tabular}

**. Correlation is significant at the 0.01 level (2-tailed).

* Correlation is significant at the 0.05 level (2-tailed).

Correlation of blood parameters and condition factor of this study (table 3) revealed that $\mathrm{PCV}, \mathrm{WBC}, \mathrm{Hb}, \mathrm{RBC}$ and plasma protein have negative relationship with the condition factor $(\mathrm{K})$ of the experimental fish. This implies that the condition of the fish have great impact on the hematological indices of the fish (Kandeepan, 2014). However, the result of this study shows that the experimental fish had condition factor $(\mathrm{K})$ of one and above, which is a confirmation of good health status of experimental fish.
In conclusion, this study shows that inclusion of melon shell in the diets does not have adverse effect on Clarias gariepinus can be conveniently used as replacement for maize in feed formulation.

\section{References}

Blaxhall, D.C., Daiseley, K.W. 1973. Routine Haematological Methods for use with Fish Blood. J. Fish Biol., 5: 771-781.

Douglass, J.W., Jane, K.W. (eds.) 2010. 
Schalm s Veterinary Hematology. John Wiley and Sons, Blackwell Publishing Ltd. 1232 pp.

Fazio, F., Marafioti, S., Arfuso, F., Piccione, G., Faggio, C. 2013. Comparative study of the Feldman, B.F., Zinkl, J.G. and Jain, N.C. 2000. Schalm's Veterinary Haematology. 5th ed. Lippincott Williams and Wilkins. pp. 1120- 1124.

Kandeepan, C. Heamatological and Biochemical Parameters on few fresh water south Indian teleaosts. Int. J. Curr. Microbiol. Appl. Sci., Volume 3(9) pp 1013-1022.

Lee, R.G., Foerster, J., Jukens, J., Paraskevas, F., Greer, J.P. and Rodgers, G.M. 1998. Wintrobe sClinical Hematology, 10th Ed. Lippincott Williams and Wilkins, New York, USA.

Omitoyin, B.O. 2006. Haematological changes in the blood of Clarias gariepinus (Burchell 1822) juveniles fed poultry litter. Livestock Res. Rural Develop., 18(11).

Patriche Tanti, Patriche, N., Bocioc, E., Coada, M.T. 2011. Serum biochemical parameters of farmed carp (Cyprinus carpio). Aquaculture, Aquarium, Conservation and Legislation. Int. J. Bioflux Soc., 4: 137-140.
Radu, D., Oprea, L., Bucur, C., Costache, M., Oprea, D. 2009. Characteristics of haematological parameters for carp culture and Koi (Cyprinus carpio Linneaus, 1758) reared in an intensive system. Bulletin UASVM, J. Animal Sci. Biotechnol., Vol. 66: 1-2.

Satheeshkumar, P., Ananthan, G., Senthilkumar, D., Khan, A.B., Jeevanantham, K. 2012. Comparative investigation on haematological and biochemical studies on wild marine teleost fishes from Vellar estuary, southeast coast of India. Comparative Clin. Pathol., 21: 275281.

Snieszko, S.F. 1960. Microhaematocrit as a tool in fishery research and management. United States Fish Wildlife Services, Scientific Report341, 15pp.

Stoskopf, M.K. 1993. Clinial pathology. In: Stoskopf M.K. (Ed.). Philadelphia, Pa: WB Saunder. Fish Med., pp. 113-131.

Sudha Summarwar, Santosh verma. 2012. Study of selected haematological indices offreshwater fish from bisalpur reservoir; Indian $J$. Fundamental Appl. Life Sci., (online) vol. 2(2): pp.51 -54.

\section{How to cite this article:}

Omovwohwovie, E.E., and Ekelemu, J.K. 2016. Effect of Dietary Treatments using Melon Shell on the Hematology of Catfish (Clarias gariepinus, Burchell 1822) Fingerlings. Int.J.Curr.Microbiol.App.Sci. 5(7): 648-653. doi: http://dx.doi.org/10.20546/ijcmas.2016.507.073 